\title{
Adaptation of Accessibility for People with Disabilities in Private and Public Buildings using Appropriate Design Checklist
}

\author{
Dr. Usama Ibrahim Badawy ${ }^{1} \mid$ Dr. Muain Qasem Jawabrah ${ }^{2} \mid$ Dr. Eng. Amjad jaeada ${ }^{3}$ \\ ${ }^{1}$ Former Professor of Architecture, Birzeit University, Birzeit \\ ${ }^{2}$ Assistant professor of Architecture, Birzeit University, Birzeit \\ 3 Works currently at the United Nation, Gaza, Palestine
}

To Cite this Article

Dr. Usama Ibrahim Badawy, Dr. Muain Qasem Jawabrah and Dr. Eng. Amjad Jaeada, "Adaptation of Accessibility for People with Disabilities in Private and Public Buildings using Appropriate Design Checklist", International Journal for Modern Trends in Science and Technology, Vol. 06, Issue 06, June 2020, pp.:125-137; https://doi.org/10.46501/IJMTST060627

\section{Article Info}

Received on 10-May-2020, Revised on 02-June-2020, Accepted on 08-June-2020, Published on 17-June-2020.

\section{ABSTRACT}

An integrated approach is required to ensure that persons with disabilities are not left alone. A combination of mainstreaming and targeted measures is necessary in all interventions. Persons with disabilities share the same primary needs as everyone else: health protection and treatment, basic services, shelter and income. The best way to address their inclusion is through mainstreaming disability in all plans and efforts. Targeted measures need to complement disability mainstreaming by addressing specific requirements that cannot be met by making general responses inclusive. Such measures do not need to add greatly to overall cost especially if the needs of the maximum number of users are considered in the initial design. As mentioned in the world bank publication 2005 that if they are considered from the design stage, ensuring accessibility can cost as little as 1\% more. This paper is came to recommendation how can we consider appropriate design checklist as guide for our initial Architecture design to Facilities accessible to people with disabilities for private and public buildings in a more descent appropriate way.

KEYWORDS: Disability inclusion, Accessibility, Urban Design, Architectural Design, Design checklist.

Copyright (C) 2014-2020 International Journal for Modern Trends in Science and Technology

DOI: https://doi.org/10.46501/IJMTST0606267

\section{INTRODUCTION}

Our general aim of this study is to integrate disabled people into society in order for them to take an active part in society and lead a normal life. To be active, a disabled person should be able to commute between home, work and other destinations. The technical aim is to provide a barrier-free environment for the independence, convenience and safety of all people with disabilities. [1].our initial design checklist should deals with the technical considerations and design provisions or measures to be taken into account in the planning of the built-up environment. This includes issues related to the design of several complementary domains: open spaces and recreational areas, local roads and pathways, the immediate vicinity of buildings, building entrances and the interiors of buildings. The checklist is expected to be a stimulus that will lead, in the long 
run, to the establishment of building and planning guidelines covering access for disabled people.

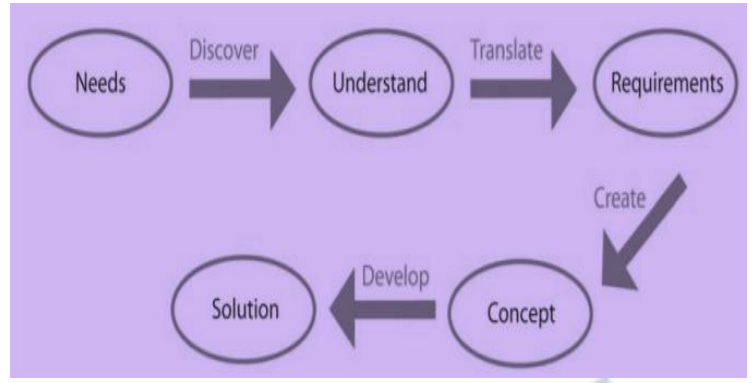

Figure 1: Inclusive design process sketches, Source authors 2020.When the building is occupied, behavioral mapping determines how people use certain spaces, where movement occurs, and possible congestion locations. As a result, various users should be integrated into the design process in order to create more accessible environments from the beginning, while learning and enhancing past design solutions.

\section{URban DESIGn Considerations}

What are the defining characteristics of Urban Design? Urban Design involves the design and coordination of all that makes up cities and towns: Compact, walkable places are the most sustainable form of living. The combination of human scale urbanism, with a mix of uses and services, a range of housing options, extensive train systems, and the ability to walk and bicycle as part of daily life all make for sustainable, green living. Add safe, clean, renewable energy, and true sustainability results. Futuristic architecture inhabitant. Urban design is the process of giving form, shape, and character to groups of buildings, to whole neighborhoods, and the city.

It is a framework that orders the elements into a network of streets, squares, and blocks. Urban design blends architecture, landscape architecture, and city planning together to make urban areas functional and attractive.

BuILDINGs: are the most pronounced elements of urban design - they shape and articulate space by forming the street walls of the city. Well-designed buildings and groups of buildings work together to create a sense of place. [2].

Public-Space: Generally, in public spaces and buildings, the required precautions are taken according to the physically disabled people like wheel chair users, visually or audible impaired individuals and the like; but, there are space solutions also for mentally and cognitively disordered people. In some country, some built environment preservation are taken only for the physically impaired people. However, some space solutions have to be searched and provided for the people who have autism, dementia or the other similar disabilities. In order to realize this, the society have to accept the behaviors that include disabled people and contribute to the formation of a fair built environment for all.

In Architectural Terminology generally the usage of public expression is sometimes used for the buildings as well as open/urbanized areas. Publicity means openness to everybody. Either closed space nor open urban area, public space carries the meaning of permission for general usage [3]. Great public spaces are the living room of the cities places where people come together to enjoy the city and each other. Public spaces make high quality life in the city possible they form the stage and backdrop to the drama of life. Public spaces range from grand central plazas and squares, to small, local neighborhood parks. Public space is conceived as open or closed spaces which constructed for the usage of every individual without any discrimination in the society (park, garden, stop etc.) ministration. Everybody has the responsibility to create solutions for the public. American Disabilities Act (ADA) is federal legislation passed in 1990 that prohibits discrimination against people with disabilities defines the accessibility as: Accessible road, is the road that from a node in the interior of a building to the public space does not include any obstacle and provides continuity. Requires meeting the basic needs of all people and extending opportunities for economic and social advancement. A development initiative is considered sustainable if, in addition to protecting the environment and creating opportunity, it is able to carry out activities and generate its own financial resources see figure $1 \& 2$.

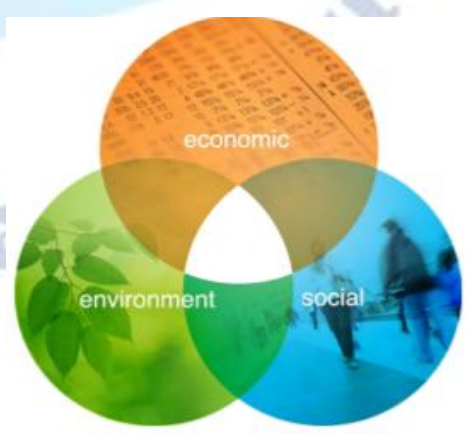

Figure 2: three pillars of sustainable design, source authors 2020.

The UN Standard Rules on Accessibility make the following recommendations regarding access to the physical environment [4]: 
- States should initiate measures to remove the obstacles to participation in the physical environment. Such measures should develop standards and guidelines and consider enacting legislation to ensure accessibility to various areas in society, including housing, buildings, public transport services and other means of transportation, streets and other outdoor environments.

- States should ensure that architects, construction engineers and others who are professionally involved in the design and construction of the physical environment have access to adequate information on disability policy and measures to achieve accessibility.

- Accessibility requirements should be included in the design and construction of the physical environment from the beginning of the design process.

- Organizations of persons with disabilities should be consulted when standards and norms for accessibility are being developed. They should also be involved locally from the initial planning stage when public construction projects are being designed, thus ensuring maximum accessibility.

Entrances and Exits: In the buildings main entrances equal right, fair usage principles have to be considered for all the users. The entrances for the disabled people have to be designed accordingly. For the passage ways, ramps, stairs, entrance doors, information and warning boards required dimensions have to be used see figure 3 . In front of the entrances space for the movement of wheel chair user has to be provided. If there is carpet on the ground floor, the material has to be fixed on the ground securely. This design standard should applies to new buildings. It should be adapted accordingly in the design of alterations or renovations to existing buildings [4].

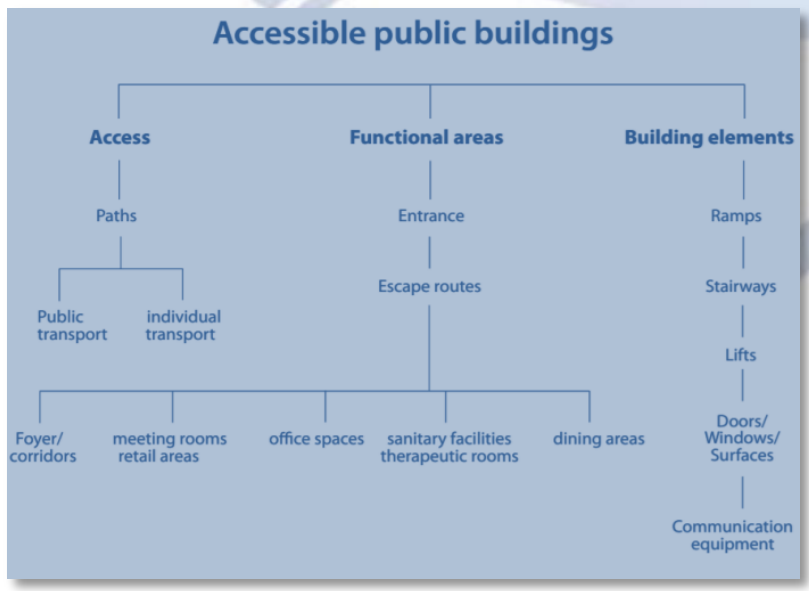

Figure 3. Accessible public building scheme, source authors 2020

\section{STREETS}

Streets are the connections between spaces and places, as well as being spaces themselves. They are defined by their physical dimension and character as well as the size, scale, and character of the buildings that line them. Streets range from grand avenues such as the Kurfürstendamm in Berlin to small, intimate pedestrian streets. The pattern of the street network is part of what defines a city and what makes each city unique [6].

\section{TRANSPORT}

Transport systems connect the parts of cities and help shape them, and enable movement throughout the city. They include road, rail, bicycle, and pedestrian networks, and together form the total movement system of a city. The balance of these various transport systems is what helps define the quality and character of cities, and makes them either friendly or hostile to pedestrians. The best cities are the ones that elevate the experience of the pedestrian while minimizing the dominance of the private automobile. At the transition areas and at the other used ramps on the roads have to have maximum 5 $\%$ slope. Vehicle Parking Areas: Vehicle parking areas have to be placed closer to the entrance and open to an accessible route. The dimensions of the disabled vehicle parking side by side with an angle are minimum $250 \mathrm{~cm} \times 250 \mathrm{~cm}$. thinking the movement of the wheel chair the distance left in between the two parking areas for the transition corridors has to be minimum 150 $\mathrm{cm}$ in width. In front of the vehicle, minimum $91.5 \mathrm{~cm}$ in width transition road has to be left (Figure 6) and [4 \&87].

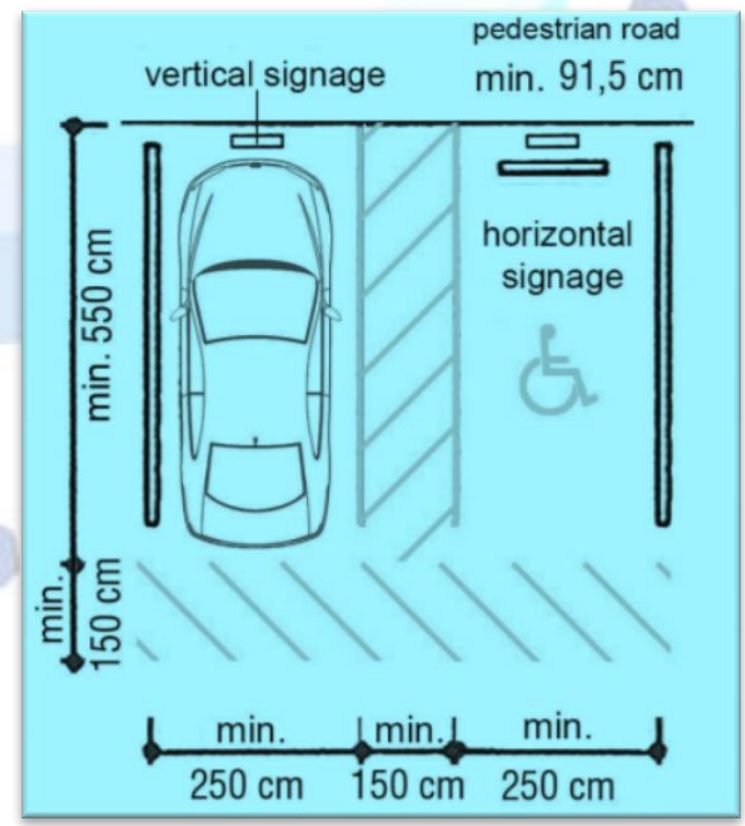

Figure 4. Vehicle Parking Area, source [4], reworked by authors. 
The materials of the roads in between the buildings and the vehicle park have to be non-slippery and matte taking into consideration the weather conditions. Others are deliberate, using specifications that anticipate your paper as one part of the entire proceedings, and not as an independent document. Please do not revise any of the current designations.

\section{Landscape}

The landscape is the green part of the city that weaves throughout - in the form of urban parks, street trees, plants, flowers, and water in many forms. The landscape helps define the character and beauty of a city and creates soft, contrasting spaces and elements. Urban Design weaves together these elements into a coherent, organized design structure and the urban design structure defines the urban form and the building form. This means to deals with the design requirements of open spaces, recreational areas and pedestrian routes. It introduces solutions to the principal problems in the design of an accessible outdoor environment. It is could be summarised as followed:

\section{Obstructions}

2. Signage

3. Street Furniture

4. Pathways

5. Curb Ramps

6. Pedestrian Crossing

\section{Parking}

Our aim in this research to shed the light of all this vital items to be included into our initial design checklist it begin from adaptation of Street furniture locating so as to allow for the free passage of all people without creating hazards. The design should take into account facilities that are accessible to people with disabilities see figure $5 \& 6$.

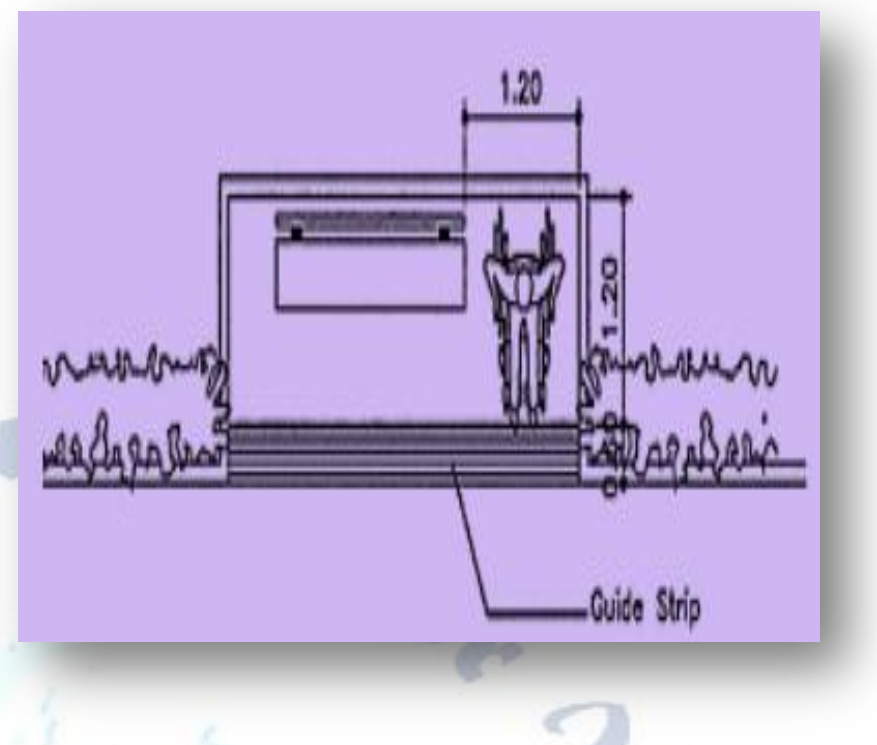

Figure5: shows sketch Facilities accessible for people with disabilities for an independent wheelchair user

Obstructions should be placed outside the path of travel wherever possible. Obstructions in the pathway should be easy to detect, and if possible, should be placed along one continuous line.

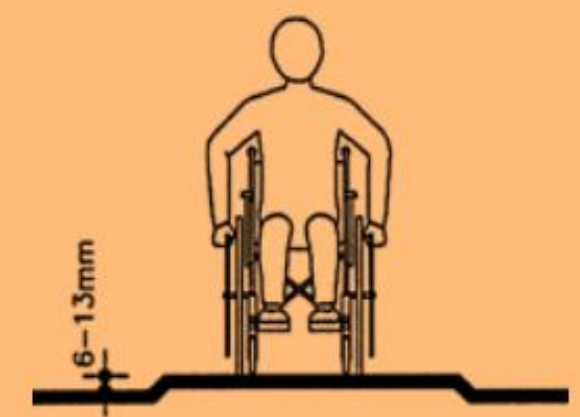

Figure 6: shows sketch maximum Obstructions for people with disabilities for an independent wheelchair user.

The road surface at pedestrian crossings can be raised to the same level as the pathway so that wheelchair users do not have to overcome differences in height. The time interval allowed for crossing should be programmed according to the slowest crossing persons. Pedestrian crossings should be equipped with traffic control signals.

\section{SURFACE:}

Should be firm not slippery, with tactile surface and contrasting color upstairs and downstairs for person with a visual impairment. Use guiding stripes on the ground, look for tiles with a typical surface and different color that can be felt by the sole of the foot to easily orientate and safely moving forward e.g., dotted tiles say "Stop or Turn", lined tiles say Go refer to the Figure7. 

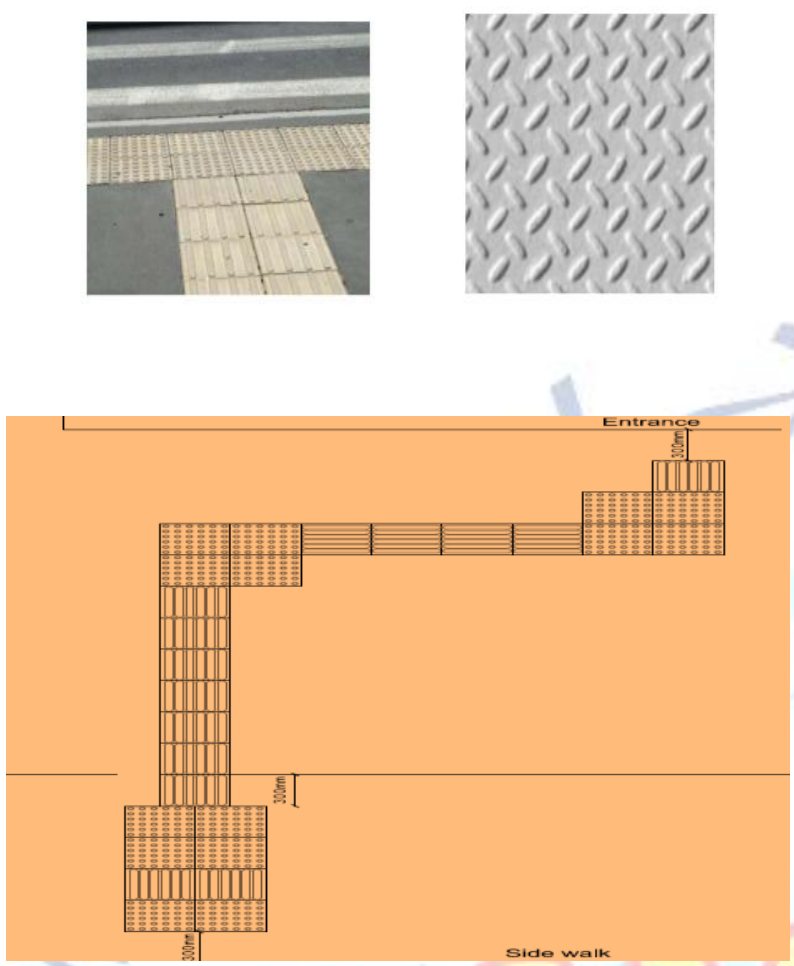

Figure 7: shows sketch approaching side wake to the building for an independent wheelchair user,

Source [7], reworked by authors.

\section{ARchitectural Design Considerations}

Its deals with the design requirements of vertical and horizontal access in both new and existing constructions. It is the design considerations are formulated to bring to the attention of the designers in applying the universal accessibility design principles and requirements to buildings and facilities. A solid functional plan is that single most important factor in obtaining an acceptable solution to the Building Program. This can best be achieved through a careful study of the space relationships and a thorough understanding of the needs of the users as expressed in the Building Program and in subsequent meetings and discussions held between the Architect and the Building Committee, see figure 1. Four levels of accessibility must be considered when designing or implementing accessible facilities or services:
1) How to Reach
2) How to Enter
3) How to Use
4)How to understand instructions and information.

The Architect shall design the building with attention not only to its relationship to nearby buildings, but to the open spaces and landscaping around it. Barrier-free environments are essential for full participation and equality of disabled people [8].
1. Ramps
2. Elevators
3. Platform Lift
4. Stairs
5. Railings and Handrails
6. Entrance
7. Vestibules
8. Doors
9. Corridors
10. Rest Rooms

The real aims of this research is to highlight the most important related points, that's gives more value and guide for designers and architects.

\section{CURB Ramps}

Construction in the form of an inclined plane that makes it possible to pass from street level to a higher accessible pedestrian path. In pedestrian crossings, when there is a height change, curb cuts shall be provided following the requirements of under mentioned figure

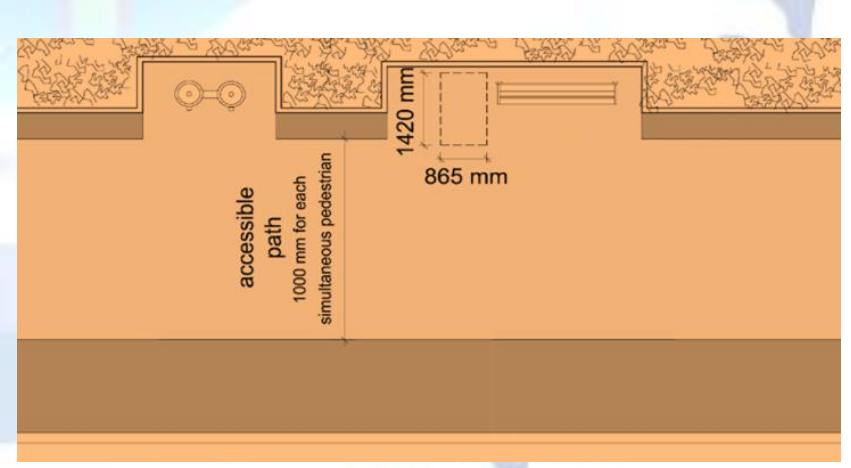

Figure 8: Accessible path of travel free of obstacles, Source: Dubai Universal Design Code Final Feb 2017 ,PP27 reworked by authors. 


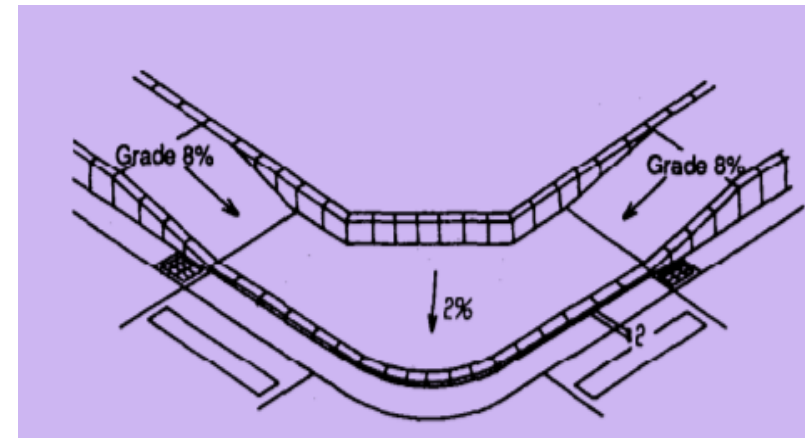

Figure 9:Sidewalk grading at intersection skitch ,authors.

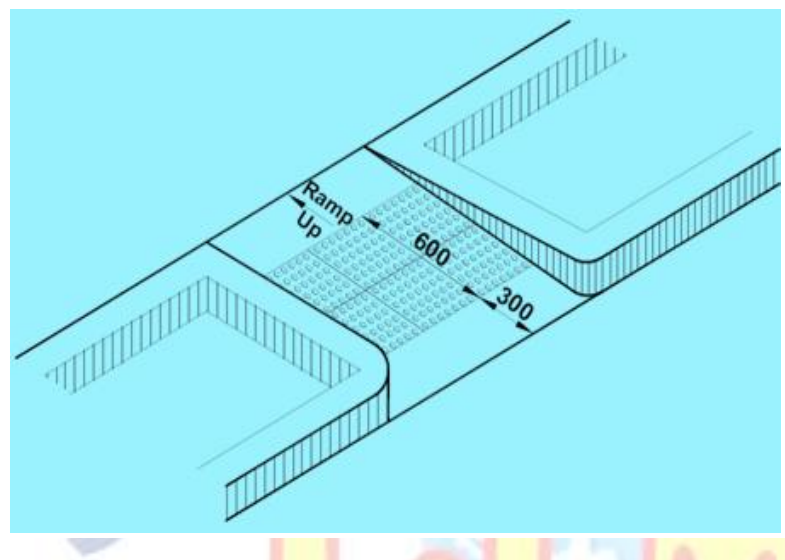

Figure 10: Source: Draft Code on Accessibilityin the Built Environmental 2019, pp30,reworked by authors.

Newly constructed or altered streets, roads, and highways must contain curb ramps or other sloped areas at any intersection having curbs or other barriers to entry from a street level pedestrian walkway, see figure 10 .

\section{RETURNED CURB RAMPS TYPES}

Returned curb ramps are comprised of a single slope placed longitudinally from the crossing direction, creating two different levels of variable heights on its sides.

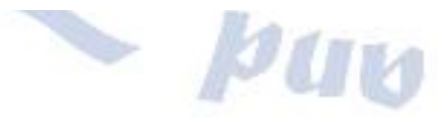

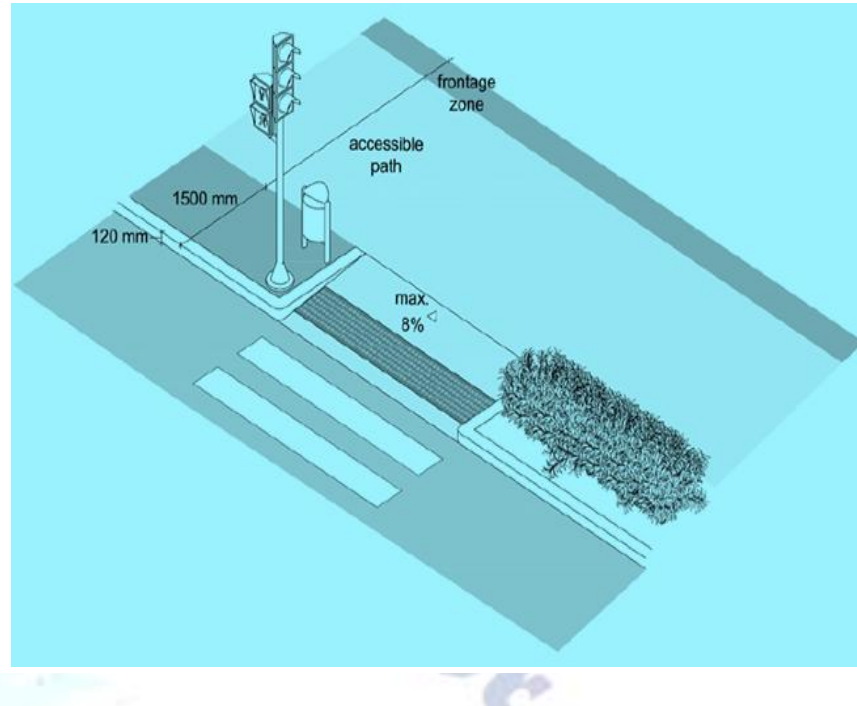

Figure 11: Source: Dubai Universal Design Code Final Feb 2017 ,PP103,reworked by authors.

\section{CURb RAMPS IN CURB EXTENSIONS}

This type is appropriate when the sidewalk is narrow. Extensions in the street corners can be created to reduce the pedestrian crossing distance, see figure $10 \& 11$.

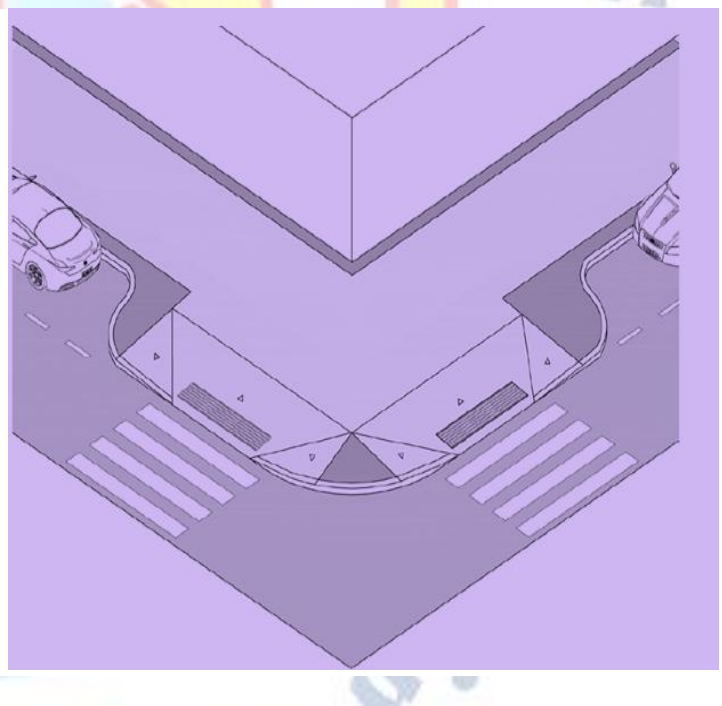

Figure 12: Source: Dubai Universal Design Code Final Feb 2017 ,PP105,reworked by authors.

\section{INTERACTION SPACE}

The interaction space is the space required by a person to interact with another person, furniture, appliance, machine or another element. This space is also used by a person to transfer from a wheelchair to a seat or a toilet or to park a pram. The interaction space shall not invade the accessible path. The interaction space can be frontal or lateral, see figure 11 . 


\section{ENTRANCES}

The accessible path from the street or public space shall avoid stairs and ramps. Gradients up to $2 \%$ are preferred, although up to $5 \%$ are acceptable to reach the main entrance(s) at street level. If over $5 \%$ it should be designed as a ramp, see figure 13 . All entrance doors must have a clear passage width adequate to the intended use of the building and the expected number of users. Minimum dimensions are $900 \mathrm{~mm}$ width $\mathrm{x} 2100 \mathrm{~mm}$ height. Doormats shall be levelled with the floor with a tolerance of $\pm 2 \mathrm{~mm}$ [9]. The wheelchair ramp gives a wheelchair user more accessibility where a vertical distance must be traversed. Types of Wheelchair Ramps: Semi-permanent ramps rest on top of the ground or padding and are commonly used for short-term solutions. Permanent ramps Long-term solutions for disability act compliance and are usually bolted or cemented in place [8]. These are best suited for new buildings or halls. Portable ramps - Made of lightweight materials and can fold for ease of transport such in berlins public transportations. It is important to find a variety that has a skid resistance surface. They are available in various metals and aluminum blends that are easy to maintain and clean. There are quite a variety of portable vehicle wheelchair ramps available. Some are just ramps while others have handrails. Deluxe versions have handrails on both sides. The old style of track wheelchair ramps is still available. These have one ramp per set of wheels for the wheel chair and are most commonly used with vehicle access. Vehicle Ramps - Vans equipped with wheelchair ramps are commonly seen at senior centers and schools where they are used to transport people with disabilities to and from public events. Many dealers sell vans with these ramps already attached - in fact it may be easier to purchase a new van rather than modify your old van to accommodate a wheelchair ramp. In America for loading unoccupied wheelchairs the ADA recommends a 3:12 slope. This means for every three inches of vertical rise you are required to have a least one foot of ramp. For business use the ADA recommends a 1:12 slope which means that every one inch of vertical rise requires one for the ramp. For example 24 inches of rise demands a 24-foot-ramp minimum. The U.K. has its own set of guidelines which are more complicated because they integrate both the metric and English terms of measurement. The reach of a wheelchair user is constrained by his seated position and the wheels of the chair and the footrest extension limit access to room corners, window opening, workbenches or switches. It is also important to consider various reaching zones for children and persons of small stature [9].

It is also important to use accessible furniture such as kitchen, table, bed, which is not only a matter of reaching but really using the equipment;

- Free space between furniture: $1.5 \mathrm{~m}$ to circulate free space under table, kitchen cooking table, counter, and oven:

- Height of furniture should be $0.8 \mathrm{~m}$ with a $0.7 \mathrm{~m}$ free space for legs below the surface - depth $0.6 \mathrm{~m}$.

- bench / bed: height above $0.45 \mathrm{~m}$ Barrier-free, design for-all, life span design, and trans generational design accessibility Therefore, inclusive environments provide access for everyone, regardless of their age and abilities[10].

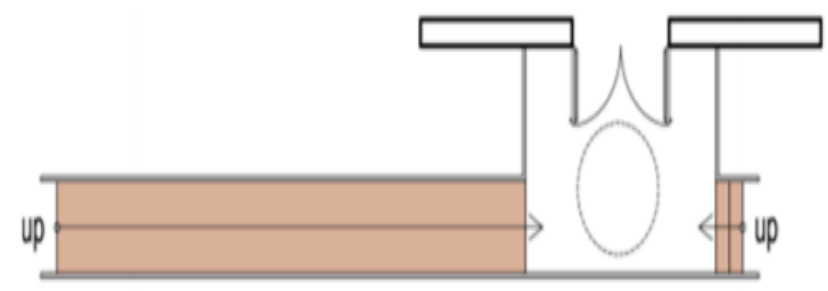

Figure 13: a main entrance with stairs and a ramp addresses accessibility

Lift, wherever you wish to create barrier-free access for use in private homes or in public areas in the technology and experience of the Hirolift Company Germany 2020.

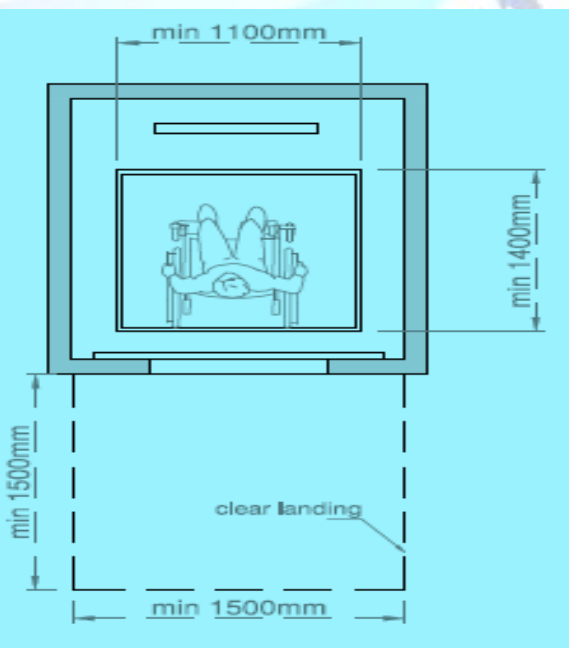

Figure 14: shows the minimum dimensions of lift for disabled people's users, source Hirolift Company Germany 2020 web site. 


\section{STEPS AND STAIRS:}

Stairways shall have handrails at both sides of all stairs. Handrails shall comply with the under mentioned figure and shall have the following features, see figure 15 :

(1) Handrails shall be continuous along both sides of stairs. The inside handrail on switchback or dogleg stairs shall always be continuous.

(2) If handrails are not continuous, they shall extend at least 12 in $(305 \mathrm{~mm})$ beyond the top riser and at least 12 in $(305 \mathrm{~mm})$ plus the width of one tread beyond the bottom riser. At the top, the extension shall be parallel with the floor or ground surface $[10 \& 11]$.

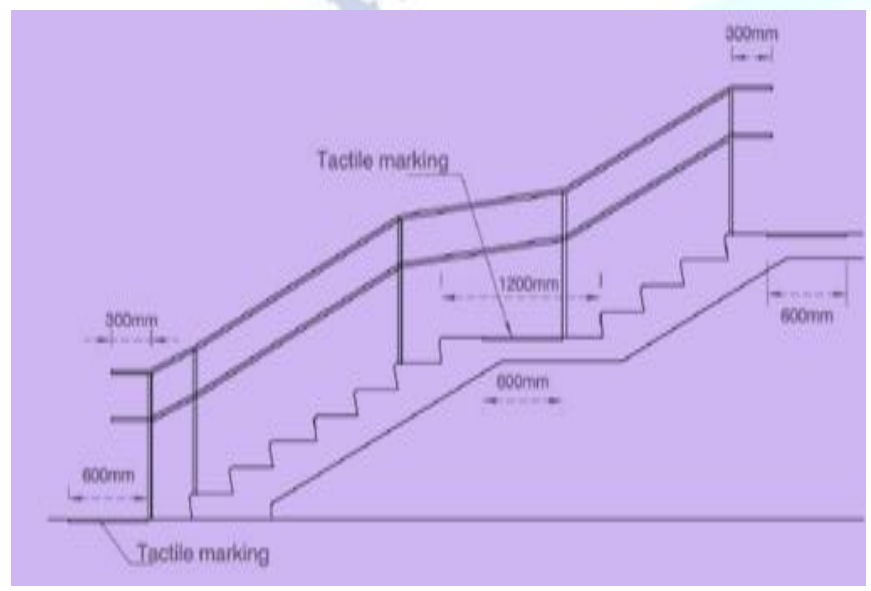

Figure 15: shows stairs and handrails relationship Source: Appendix A to Part 1191 - Americans with Disabilities Act (ADA) Accessibility Guidelines for Buildings and Facilities pp35.

To facilitate use by ambulant disabled and elderly people, handrails should be mounted between 0.85 $\mathrm{m}$ and $0.95 \mathrm{~m}$ above the finished floor level.

-Handrails shall have two heights; the upper at 850 $\mathrm{mm}-900 \mathrm{~mm}$ and the lower at $700 \mathrm{~mm}$ (for children) from ground level [10\&11].;

- Handrail top is $850 \mathrm{~mm}-900 \mathrm{~mm}$ above the surface of a ramp or the pitch line of a flight of steps and $1000 \mathrm{~mm}$ above the surface of a landing; Handrails should allow a firm and easy grip.

- Circular cross-sections with a diameter of 40 $\mathrm{mm}$ are preferable.

- Sharp edges should be avoided.

Handrails should extend horizontally for a distance between $0.30 \mathrm{~m}$ and $0.45 \mathrm{~m}$ at the top and bottom of stairs and ramps, except in places where extensions could obstruct the pedestrian flow (fig. 16) and [10\&11.

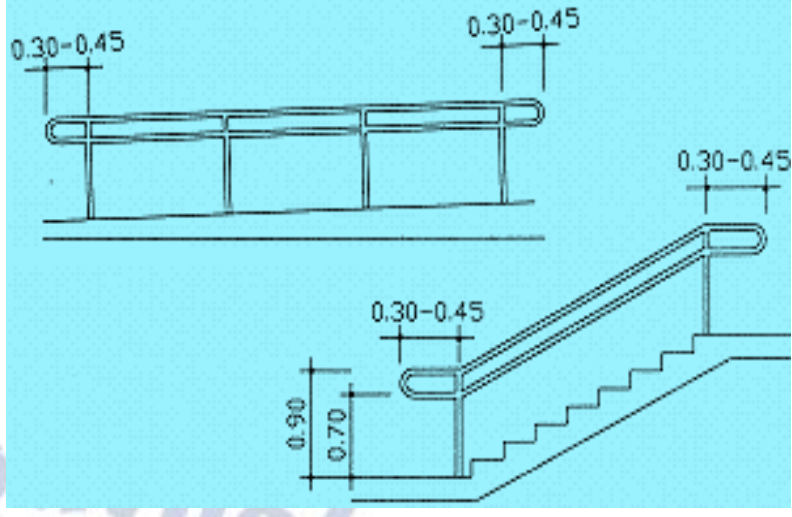

Figure 16:Handrail details, Source: Appendix A to Part 1191 - Americans with Disabilities Act (ADA) Accessibility Guidelines for Buildings and Facilities pp35.

\section{Slope SPECIFICATIONS:}

Having the correct slope is crucial as an overly steep slope can render a ramp too dangerous and inaccessible for an independent wheelchair user. Preferably there should be no vertical (very steep) slope at all. The preferred slope is $5 \%(1 \mathrm{~cm}$ height: $20 \mathrm{~cm}$ length) and the maximum acceptable slope is $8 \%$ ( $1 \mathrm{~cm}$ height: $12 \mathrm{~cm}$ length) A slope of $12 \%$ is not ideal and only acceptable if it is for short distance $50 \mathrm{~cm} \mathrm{[12].}$

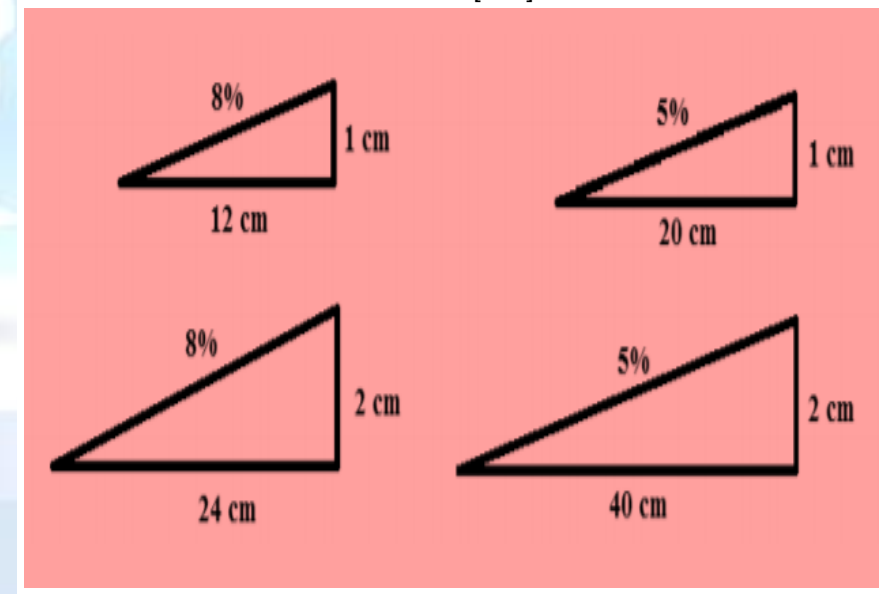

Figure 17: shows sketch explanation of slope ramp for an independent wheelchair user.

\section{CORRIDORS DESIGN CONSIDERATIONS}

Provision of well-dimensioned corridors to facilitate the passage and maneuvering of a wheelchair. The unobstructed width of a low-traffic corridor should not be less than $0.90 \mathrm{~m}$. This also allows maneuverability in 90 turns. The unobstructed width of a public corridor should not be less than $1.50 \mathrm{~m}$. The recommended width is $1.80 \mathrm{~m}$. degree turn is $1.50 \mathrm{~m} * 1.50 \mathrm{~m}$, see figure 18 . Narrow 
corridors should be widened along their full length if feasible; otherwise, passing areas should be located at appropriate intervals along the corridor length. The minimum width of the passing area should be $1.50 \mathrm{~m}$ and the minimum length should be $2.40 \mathrm{~m}$. In highly restricted spaces, the height of an obstacle or sign can be dropped to $1.95 \mathrm{~m} .1 .50$ $\mathrm{m}$ is the minimum width for two wheelchairs to pass each other or for one wheelchair to make a full turn, see figure $18,[12]$.

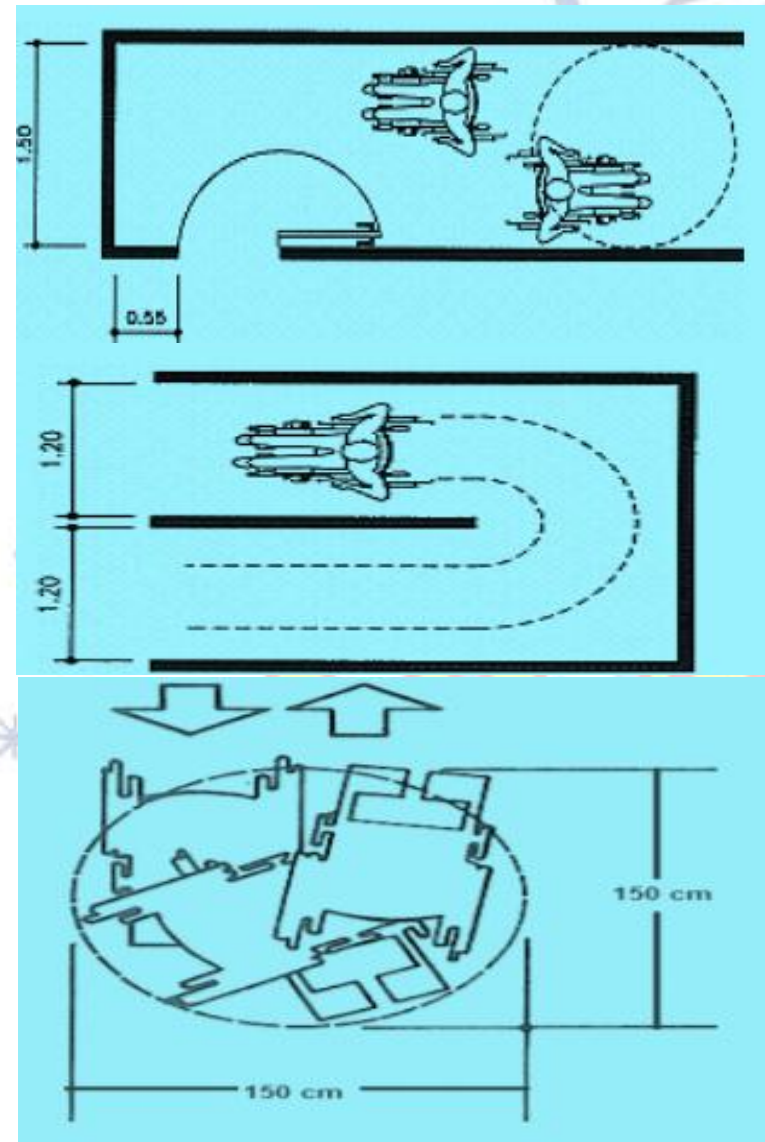

The space required for a wheelchair to make a 360

Figure 18: shows the space required to turn a wheelchair at various spaces, source [12].

\section{BuILDing TyPES}

It deals directly with the accessibility requirements of selected building types. Special buildings for people with disabilities, such as health and residential facilities and schools, fall within the scope of this item. In order to define buildings and plans for access for disabled people, this must be thoroughly developed through architectural designs based on the size of the target group, a classification of the different building types.

\section{General Considerations for Public BUILDINGS}

- Fear of safety/new people: In public places we you need to meet someone, try to meet him with one of his family members or friend present.

- Space issues (claustrophobia): When designing a public building take in consideration the dimensions of the rooms, it is preferable to have a large space to meet people.

- Fear of getting lost: Always try to meet people in a location where it is easier for them to enter and exit the place.

\section{ARChitectural Design Checklist Consideration}

The aim of design Checklist Application is intended to be a tool used by Architect to assess and to develop proper solutions without missing any items related with accessibility, see figure 19 .

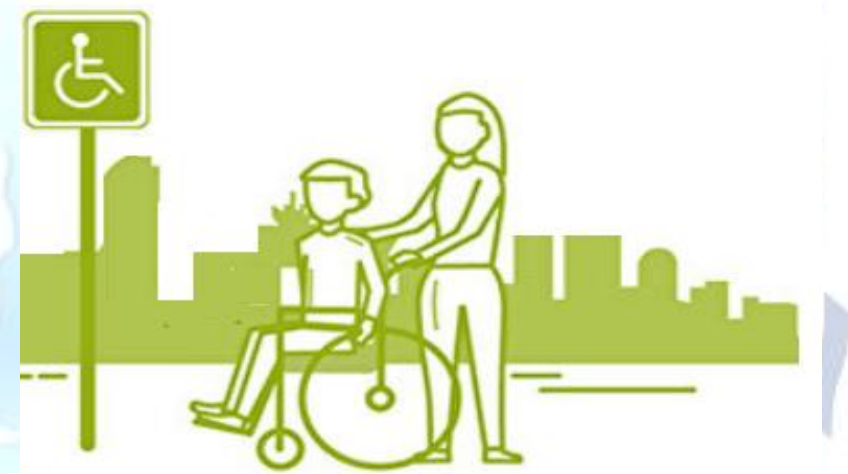

Figure 19: shows some required Checklist items to be considered in Barrier-free Accessibility design.

\section{PROPOSED DESIGN CHECKLIST}

Part 1: Building or Compound surroundings and outdoor areas

\begin{tabular}{|l|l|l|l|}
\hline SL & Checklist Items: & Ye & N \\
& & o \\
\hline 1 & External Space (outdoor areas) & & \\
\hline 1.1 & $\begin{array}{l}\text { Accessible path free of obstacles } \\
>1200 \mathrm{~mm}\end{array}$ & & \\
\hline
\end{tabular}




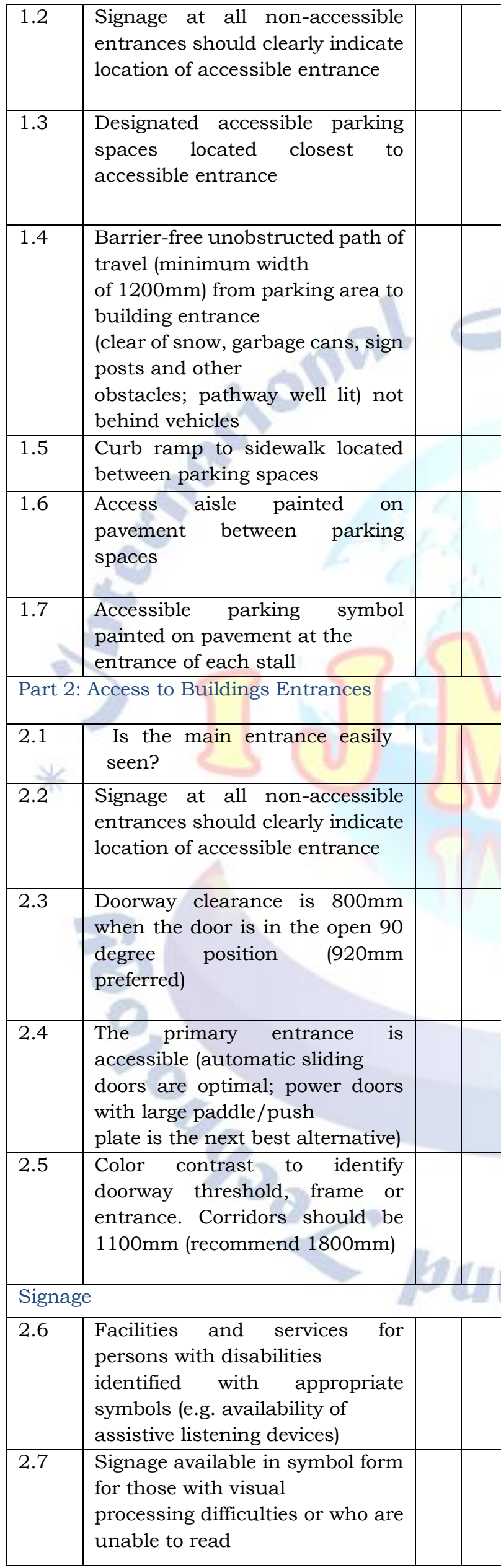

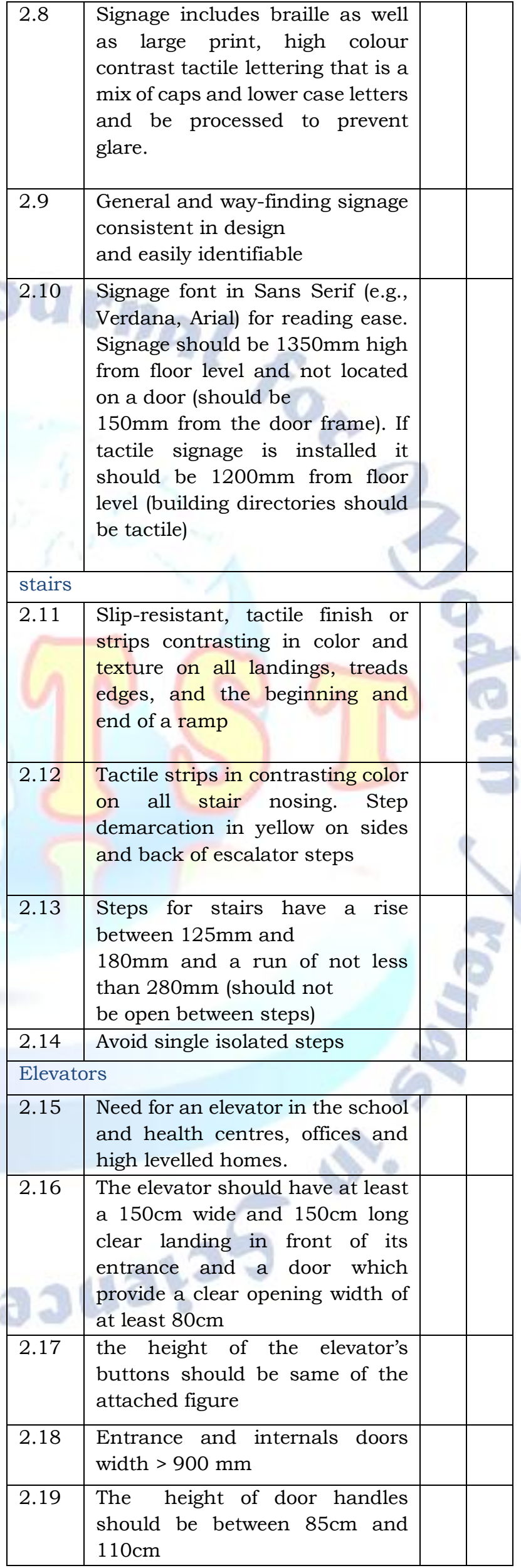




\begin{tabular}{|c|c|}
\hline 2.20 & $\begin{array}{l}\text { Doors have clear colour contrast } \\
\text { from door surroundings }\end{array}$ \\
\hline 2.21 & $\begin{array}{l}\text { Location of elevators clearly } \\
\text { identified at main entrance }\end{array}$ \\
\hline 2.22 & $\begin{array}{l}\text { Braille and tactile numbers } \\
\text { placed on both sides of } \\
\text { door jams at appropriate height } \\
\text { to identify floor level }\end{array}$ \\
\hline 2.23 & $\begin{array}{l}\text { Elevator buttons and emergency } \\
\text { controls incorporate large print } \\
\text { tactile numbers and Braille } \\
\text { mounted in a raised fashion (not } \\
\text { flush or recessed) }\end{array}$ \\
\hline 2.24 & $\begin{array}{l}\text { Visual indicator in elevators to } \\
\text { indicate "help on the way" for use } \\
\text { in an emergency }\end{array}$ \\
\hline \multicolumn{2}{|c|}{ Ramps } \\
\hline 2.25 & $\begin{array}{l}\text { Strong color contrast and tactile } \\
\text { surfacing on all ramp landings } \\
\text { and a } 15 \mathrm{~mm} \text { wide strip in } \\
\text { contrasting color and texture at } \\
\text { the top of ramp to warn users of a } \\
\text { change in elevations }\end{array}$ \\
\hline 2.26 & $\begin{array}{l}\text { Ramps that allow persons using } \\
\text { wheelchairs to move } \\
\text { independently shall not exceed a } \\
\text { slope of } 8 \%(1: 12) \text {. }\end{array}$ \\
\hline 2.27 & $\begin{array}{l}\text { Landings designed to } \\
\text { accommodate larger chairs and } \\
\text { scooters (able to open door } \\
\text { without backing onto ramp). } \\
\text { Landings must be min } 1200 \mathrm{~mm} \\
\text { long. }\end{array}$ \\
\hline \multicolumn{2}{|c|}{ Handrails } \\
\hline 2.28 & $\begin{array}{l}\text { Handrails provided at two } \\
\text { heights with unobscured view } \\
\text { between. Handrail height should } \\
\text { be } 900 \mathrm{~mm} \text { and another at a } \\
\text { height of } 700 \mathrm{~mm}\end{array}$ \\
\hline
\end{tabular}

\begin{tabular}{|c|c|c|c|}
\hline 2.29 & $\begin{array}{l}\text { Two continuous handrails on } \\
\text { both sides of steps, one at } 90 \mathrm{~cm} \\
\text { and one at } 70 \mathrm{~cm} \text { are required }\end{array}$ & & \\
\hline 2.30 & $\begin{array}{l}\text { Handrails extend horizontally } \\
\text { beyond last stair and terminate } \\
\text { to wall or ground }\end{array}$ & & \\
\hline \multicolumn{4}{|c|}{ Toilets } \\
\hline 2.31 & $\begin{array}{l}\text { The toilets location should be } \\
\text { visible sign indicating in } \\
\text { accessible format (e.g. Braille, } \\
\text { Contrasting colors }\end{array}$ & & \\
\hline 2.32 & $\begin{array}{l}\text { Each toilet for persons with } \\
\text { wheelchair should have an } \\
\text { unobstructed turning space of at } \\
\text { least } 150 \mathrm{~cm} \times 150 \mathrm{~cm} \text { to enable a } \\
\text { person using a wheelchair to } \\
\text { manoeuver }\end{array}$ & & \\
\hline 2.33 & $\begin{array}{l}\text { the total dimension of the toilet } \\
\text { is at least } 175 \mathrm{~cm} \times 200 \mathrm{~cm}\end{array}$ & & \\
\hline 2.34 & $\begin{array}{l}\text { The minimum number of } \\
\text { students' toilet cubicles that } \\
\text { should be provided for the use of } \\
\text { girls and boys in a } 25 \text { classrooms } \\
\text { double shift boys and girls school } \\
\text { is } 25 \text { toilet cubicles }\end{array}$ & & \\
\hline 2.35 & $\begin{array}{l}\text { the door handles should be } \\
\text { positioned at a height of between } \\
85 \mathrm{~cm} \text { and } 110 \mathrm{~cm}\end{array}$ & & \\
\hline 2.36 & $\begin{array}{l}\text { The toilet seat a height should be } \\
\text { between } 46-48 \mathrm{~cm}\end{array}$ & & \\
\hline 2.37 & $\begin{array}{l}\text { Handrails should be fixed on the } \\
\text { wall next to the toilet seat at the } \\
\text { exact height. }\end{array}$ & 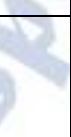 & \\
\hline 2.38 & $\begin{array}{l}\text { water taps should be easy to } \\
\text { reach and use for children with } \\
\text { different disabilities }\end{array}$ & & \\
\hline 2.39 & $\begin{array}{l}\text { toilet paper reachable without } \\
\text { leaning too far off toilet }\end{array}$ & & \\
\hline \multicolumn{4}{|c|}{ Interior Building Elements } \\
\hline 3.1 & $\begin{array}{l}\text { Space for persons using } \\
\text { wheelchairs to sit/park in all } \\
\text { public seating areas, including } \\
\text { companion seating(without } \\
\text { blocking walk through areas) }\end{array}$ & & \\
\hline
\end{tabular}




\begin{tabular}{|c|c|}
\hline 3.2 & $\begin{array}{l}\text { Level wheelchair seating area (in } \\
\text { theatres, lecture halls, sports } \\
\text { arenas etc.), to also include } \\
\text { companion seating and } \\
\text { unobstructed views }\end{array}$ \\
\hline 3.3 & $\begin{array}{l}\text { Glass doors or partitions include } \\
\text { a contrasting strip of color across } \\
\text { at eye-level }\end{array}$ \\
\hline 3.4 & $\begin{array}{l}\text { All alarm systems to include an } \\
\text { audible and visual signal (e.g., } \\
\text { flashing light) }\end{array}$ \\
\hline \multicolumn{2}{|c|}{ Furniture } \\
\hline 4.1 & $\begin{array}{l}\text { Furniture should only be placed } \\
\text { outside the main path } \\
\text { of travel (inside or outside) and is } \\
\text { detectable by } \\
\text { someone who uses a cane }\end{array}$ \\
\hline 4.2 & $\begin{array}{l}\text { There should be good colour } \\
\text { contrast between street } \\
\text { furniture and background } \\
\text { surfaces (generally, grey } \\
\text { colours should be avoided as } \\
\text { they blend into the } \\
\text { general background) }\end{array}$ \\
\hline 4.3 & $\begin{array}{l}\text { Variety of benches should be } \\
\text { provided (some } \\
\text { including a back and an arm } \\
\text { rest) }\end{array}$ \\
\hline
\end{tabular}

\section{RECOMMENDATIONS}

People with disabilities should be able to arrive on the premises, approach the building and enter as freely as everyone else.At least one route of travel (e.g., from a parking lot in front of the building to the entrance of an office within the building) should be safe and accessible for everyone, including people with disabilities.

Our aims by preparing this research to great clear checklists not only to understand from Architect designer, but also from others. Checklists should be a tools to examine their facilities and identify physical barriers that may prevent persons with disabilities from having equal access to their services. This could be essay to evaluate your facilities for physical accessibility?
Its helps us to give answers of: Do you ensure that places where you carry out your services and activities are accessible?

When you look for new space to lease or use, do you make every effort to find space that meets accessibility requirements or can be altered to meet them?

When reviewing the program reports, do you ensure that people with disabilities are included in the program activities in a meaningful and effective way?

You can use this checklist to asses where you are and identify the areas where you need to improve. We encourage all to use this checklist as a way to strengthen their own knowledge and ensure that the final proposal is truly inclusive. This checklist is intended as a guide for better Change to guide planning and programming to ensure that their final application incorporates disability inclusionary practice.

\section{Conclusion}

Inclusive design is not just about designing for people with disabilities. It's about keeping the diversity and uniqueness of each individual in mind as you create all your communications materials. It's about knowing your users, understanding what their accessibility challenges are, and adjusting your design approach to ensure that each and every one of them can successfully engage with your platform. A checklist role helps to determine how well you're align with the principles of Universal Design for disability persons.

\section{REFERENCES}

[1] Department of Economic and Social Affairs united nation, 2003, Accessibility for the Disabled - A Design Manual for a Barrier Free Environment

[2] Gürallar, Neşe (2009) Kamusal Alan, Mimarlık 350 Dergisi, Kasim - Aralik.

[3] Aruri, N. (2013). Ramallah: From "sumud" Resilience to Corporate Identity. Planum, The journal of Urbanism $1-13$.

[4] Arvanitis, A. V. (2004) People with a Disability in Modern Society, Published by Biopolitics International Organization, ISBN 960-7508-20-3, Athens.

[5] Koca, D. ve Y1lmaz, M. (2017) Engelliler İçin Mekan Düzenlemelerinde Kapsayıcı Tasarım, Yok yayını, Ankara.

[6] ClimaSouth Technical Paper N.2 (2016). The Economics of Climate Change in the Palestine. February 2017. Prepared by: Tippmann, R. and Baroni.

[7] Dubai Universal Design Code Final Feb 2017, PP27 British Standard 8300, Design of buildings and their approaches to meet the needs of disabled people - Code of practice, 2009 
[8] Disability Standards for Accessible Public Transport (Australia)

https://www.legislation.gov.au/Details/F2011C00213

Americans with Disabilities Act (ADA) Accessibility

[9] Guidelines for Buildings and Facilities, Appendix A to Part 1191 - Americans with Disabilities Act (ADA) Accessibility Guidelines for Buildings and Facilities, July 1, 2002.

[10] International Best Practices in Universal Design http://gaates.org/wp-content/uploads/2014/pdf/BP_en glish.pdf

[11] International Best Practices in Universal Design http://gaates.org/wp-content/uploads/2014/pdf/BP_en glish.pdf, Center for Inclusive Design and Environmental Access. (2010).

[12] Design Resources: Architectural Way finding. Center for Inclusive Design and Environmental Access. Retrieved June 26, 2014.

http://udeworld.com/documents/designresources/pdfs /ArchitecturalWayfinding.pdf

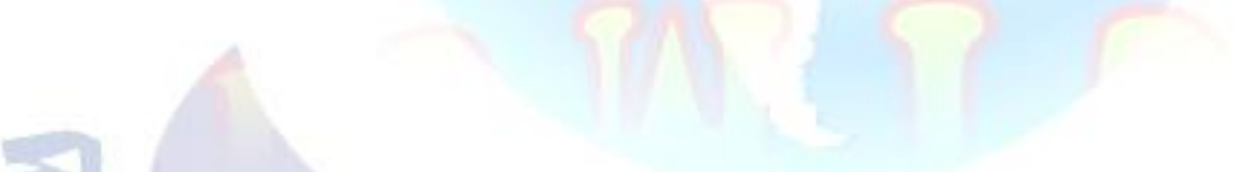

